Cad. Benjaminianos, Belo Horizonte, v. 13, n. 2, p. 315-336, 2017

\title{
Freud com Kafka: a linguagem do estrangeiro
}

\section{Freud with Kafka: the foreigner's language}

\author{
Alessandra Affortunati Martins Parente \\ Universidade de São Paulo (USP), São Paulo, São Paulo / Brasil \\ aamparente@gmail.com
}

Resumo: $\mathrm{O}$ artigo trata da linguagem do estrangeiro como forma estilística em Kafka e na obra $O$ homem Moisés e a religião monoteísta de Freud. Tal forma só pode ser explicitada de maneira precisa a partir dos textos de Walter Benjamin dedicados à linguagem e à tradução. A linguagem divina difere-se da humana condenada, após a queda, ao caráter prolixo do julgamento e à abstração vã e infeliz de línguas que escapam às coisas que pretendem designar. Na tarefa da tradução, fiel ao caráter estrangeiro dos nomes, há, porém, uma forma de linguagem humana que se mantém rente às próprias coisas, sem nunca capturá-las, mas sem recair também na abstração vazia do julgamento.

Palavras-chave: estrangeiro; tradução; Kafka; Freud; Benjamin.

\begin{abstract}
The article deals with the language of the foreigner as a stylistic form in Kafka and in Freud's work Moses and the monotheism. Such a form can only be explicitly explained from Walter Benjamin's texts devoted to language and translation. The divine language differs from the condemned human, after the fall, to the long-winded character of judgment, and to the vain and unhappy abstraction of tongues which let escape the things they intend to designate. In the task of translation, faithful to the foreign character of names, there is, however, a form of human language that remains close to one's own things, without ever catching them, but without reverting to the empty abstraction of judgment.
\end{abstract}

Keywords: foreign; translation; Kafka; Freud; Benjamin. 
Minha língua é o alemão. Minha cultura, minhas conquistas são alemãs.

Espiritualmente considerava-me como um alemão, até que notei o aumento de preconceitos antissemitas na Alemanha e na Áustria. Desde então, prefiro ser tratado como judeu.

(Freud)

Quando os olhos de um leitor de Freud se desviam das linhas que detêm o conteúdo para fixarem-se nos contornos formais de $O$ homem Moisés e a religião monoteísta, não raro sofrem certo impacto atormentador. Redator meticuloso, Freud sempre ousou muito dentro das normas estilísticas formalmente aceitas em diferentes campos institucionais. Herdeiro da alta cultura europeia - Goethe, Schiller, Shakespeare, Kant, Nietzsche etc. -, certamente atravessou suas balizas, mas nunca se atreveu a destruí-las. Pelo contrário: era mestre em alargar campos, sempre tecendo elos entre certos parâmetros clássicos e iluministas e as sombras de objetos ofuscados sob suas luzes. Hábil em expor passo a passo suas ideias, seguidas frequentemente de imagens ricas e capazes de ilustrá-las, foi contemplado com o prêmio Goethe justamente pela forma estilística de sua escrita.

Ao primeiro impacto causado pelo trabalho dedicado a Moisés segue-se certa confusão: vários prefácios e notas preliminares, trechos repetidos, partes curtas que mereceriam maior dedicação e outras extensas já anteriormente tratadas. Moisés claramente esgarça as linhas que definiam certas características formais da obra freudiana. O susto poderia, de todo modo, ser apaziguado pelos comentários de James Strachey:

O que talvez tenha probabilidade de impressionar em primeiro lugar o leitor, a respeito de $O$ homem Moisés e a religião monoteísta, é certa inortodoxia, ou mesmo excentricidade, em sua construção: três ensaios de tamanho bastante diferente, dois prefácios, ambos situados no início do terceiro ensaio, e um terceiro ensaio, e um terceiro prefácio localizado na metade deste último, recapitulações e repetições constantes. Essas irregularidades são desconhecidas nos outros trabalhos de Freud, ele próprio as aponta e por elas se desculpa mais de uma vez. Explicação? Indubitavelmente as circunstâncias da composição do livro: o longo período - quatro anos ou mais - durante o qual foi constantemente revisado, e as agudas dificuldades externas da fase final, com uma sucessão 
de distúrbios na Áustria que culminaram na ocupação nazista de Viena e a migração forçada de Freud para a Inglaterra. (STRACHEY apud FREUD, 1939/1996, p. 16).

Concederemos o benefício da dúvida ao texto sobre Moisés, sem aceitar, por conseguinte, a explicação indubitável dada por Strachey. Isso por várias razões. Em primeiro lugar: ao contrário do que sugere Strachey, o período histórico turbulento, que culminou na ascensão do nazismo, não é fator externo ou óbice para a lapidação do texto. Os episódios históricos da época estão, ao contrário, incrustrados em cada detalhe dessa obra freudiana. Mais: cada linha do texto carrega frações arquetípicas que implodem os alicerces nos quais o próprio Freud havia se apoiado, até então, para erguer sua psicanálise. Em 1934 Freud não olha para Moisés da mesma forma como o fizera em 1914, diante da estátua de Michelangelo. Longe de contemplar um Moisés que contém sua ira, Freud manda às favas sua idealizada herança cultural teuto-helênica, embebida de clássicas imagens renascentistas, e resgata suas origens judaicas para gritar contra a perniciosidade nazista, também oriunda desse berço clássico ocidental. Recuperar o repertório judaico, por tanto tempo recalcado, não condiz, vale frisar, com movimentos cujos sabores seriam nostálgicos ou até ligados a certa espécie de sionismo redentor. Freud parece antes servir-se de um turbilhão de imagens longínquas - tanto de sua vida pessoal, como da história das civilizações - que o arrebatam naquele instante político da Europa. Com essas figuras, expõe tensões profundas do passado que ainda fazem trepidar as malhas do presente.

Em segundo lugar: seguindo essa lógica, a aparente desorganização formal de Moisés aparece, então, não como uma falha a ser relevada em nome de um bom conteúdo, como ainda propõe Strachey (apud FREUD, 1939/1996): “[...] julgar que a O homem Moisés e a religião monoteísta falta algo na forma da apresentação não se destina a acarretar uma crítica do interesse de seu conteúdo ou da força convincente de seus argumentos" (p. 16) Essa suposta precariedade formal revela-se, antes, como a mais precisa e coerente com o conteúdo abordado.

Por último, mas não menos importante: manter-se fiel às balizas estabelecidas pela cultura teutônica em vigor custava certo preço. Freud o pagava, sem pesar. Em geral, o que se observava até Moisés era certo abrandamento dos certames políticos que faziam parte de seu entourage. Evita o confronto direto, fazendo breves menções a eventos polêmicos 
em notas de rodapé ou em alusões distantes. ${ }^{1}$ Salvo algumas exceções, Freud detinha seus interesses voltados aos limites da psicanálise, mesmo quando se arriscava por outros territórios; raramente explicitava conflitos sócio-políticos que afloravam em seu presente.

O que muda, então, com o Moisés? Algumas características merecem ser consideradas. Antes de tudo, seu caráter de urgência. Freud tem pressa em publicá-lo. Pressa que denota seu vínculo com o momento. Tenta fazê-lo ainda em Viena. Teme que o conteúdo desagrade a Igreja, que supunha protegê-lo naquele período. Ainda que perigos fatais o impedissem de publicar logo seu trabalho, explicita cada um desses entraves de ordem política e situa o texto naquele momento histórico, como comprovam as Notas Preliminares I e II. O que a irregularidade dessas notas e prefácios mostra é uma disposição inteiramente diferente: suas posições políticas, quase sempre relegadas a meros apensos do conteúdo central, ganham agora o corpo da obra e estão embrenhadas no assunto nela tratado. Presente e passado se mesclam e um caráter de emergência toma o leitor que se vê convocado a ler os temas do Pentateuco embebido dos acontecimentos entre 1933, com a ascensão de Hitler ao poder, e 1939, ano em que o texto é integralmente publicado e Freud vem a falecer.

A cartografia que ronda o presente jamais é capaz de apreender todos os seus ínfimos traços - há sempre algo que não pode ser agarrado no instante atual. Evocar os desdobramentos do passado significa, então, cercar a consistência do agora, inabsorvível isoladamente. A figura freudiana de Moisés faz vibrar a consistência dos eventos contemporâneos à escrita do texto, mas só é capaz de resvalar em suas malhas ao cercar o que as compõe - a fagulha do tempo do agora só pode ser detida quando cingida pelos contornos do outrora. Por isso, falar daquilo que é mais íntimo implica tratar o mais estranho, longínquo, alheio. Olhar Moisés sob um prisma crítico à versão oficial das interpretações talmúdicas, significava se despir de unidades identitárias que sustentavam a ideologia nazista, mas também a sionista.

Nesses cruzamentos de tempos e espaços, cabe sublinhar o caráter estrangeiro de Moisés em uma de suas camadas: o fato de ser considerado "pesado de língua" [schwer von Sprache]. Essa característica é lembrada

\footnotetext{
${ }^{1}$ Não será possível demonstrar esse aspecto nesse espaço. Tentei elucidar a forma como isso ocorre nas obras freudianas a partir de um exemplo. Cf. em Subl e Unheiml. Aspectos mais evidentes de que confrontos políticos Otto Gross e reich.
} 
por Freud sob uma nova luz. Na versão oficial do Exxodo, um suposto distúrbio da fala [gagueira] ou inibição teriam exigido um intérprete: Aarão, que o representa nas negociações com o povo israelita e com o faraó. Freud, porém, levanta outro argumento: Moisés é estrangeiro. Por falar outra língua não pode articular palavras que sejam compreensíveis nem aos israelitas - com quem se identifica - nem ao faraó - com quem compartilha as bases de sua formação. A frase mais citada "Perdão meu senhor, eu não sou um homem de falar [...], pois tenho a boca pesada, e pesada a língua", repete-se em outras passagens do Exodo com algumas variações. O que ela pode, afinal, querer dizer? Responder a essa questão exigirá certa digressão nesse ponto.

\section{0 caso Kafka e a linguagem do estrangeiro}

Em Who owns Kafka? Judith Butler (2011) trata dos diferentes itinerários percorridos pelo espólio de Kafka após um processo judicial ter sido aberto, visando determinar quem - ou que instituição e de que país - deveria deter os direitos sobre a coleção de documentos e manuscritos, alguns deles inéditos. Pelas indicações acrescidas ao inventário, Max Brod, sabe-se, deveria destruir o trabalho de Kafka. Seu amigo, contudo, não seguiu tais instruções, publicando entre 1925 e 1927 O Processo, O Castelo e Amerika. Seria por demais enfadonho repertoriar aqui todos os destinos percorridos por esse material após a morte de Max Brod. O que cabe agora destacar são alguns dos diferentes argumentos usados por aqueles que disputam esse valioso tesouro.

Antes, porém, de adentrar esse tópico da palestra de Butler (2011), convém apresentar as razões pelas quais Franz Kafka aparece neste trabalho dedicado a Moisés. Poderíamos justificar a aproximação - que a essa altura parece mais um salto inconsequente - da escrita de Kafka com alguns elementos do Moisés de Freud com o frágil argumento de que o escritor tcheco, assim como Freud, eram personagens oriundos do dissolvido Império Austro-húngaro. A língua alemã e o judaísmo também os torna diretamente irmãos em vários aspectos. Não só isso. O prisma ambíguo pelo qual olham o sionismo, mas também a cultura alemã seria, talvez, suficiente para enredá-los mais estreitamente. Embora esses elos pareçam conectá-los, essas não são as razões pelas quais valeria o esforço de explicitar os meandros desse vínculo. 
É em Anotações sobre Kafka que encontramos os motivos que compensam o empenho de estabelecer essas relações. Lá, Theodor Adorno (1955/1996) sublinha que, para entender Kafka, mais vale uma leitura imanente de sua obra, em tentativas de decifrar algumas cenas, do que fazer do autor uma mera ilustração de ontologia. De qualquer maneira, insiste que uma aproximação entre o autor tcheco e Freud é extremamente reveladora. Na visão de Adorno, entre outros aspectos, a semelhança no modo como ambos tratam a hierarquia deve ser especialmente notada. Nesse rol, merece especial atenção o paralelo entre "cenas arquetípicas como a do assassinato do pai pela horda primordial" ou "a narração [...] de Moisés" (ADORNO, 1955/1996, p. 246) e as construções literárias kafkianas. Cenas ancestrais que se sedimentam psiquicamente formando os alicerces de uma arquitetura psíquica. Para Adorno, "nessas excentricidades, Kafka segue Freud até o absurdo" (ADORNO, 1955/1996, p. 246). É impressionante como Adorno é perspicaz ao perceber que Freud "arranca a psicanálise do âmbito da psicologia [...] na medida em que deduz o indivíduo a partir de impulsos amorfos e difusos, o Ego a partir do Id" (ADORNO, 1955/1996, p. 246). Freud, como Kafka, dilui a vigência da alma. No lugar da ideia de personalidade, entendida como entidade substancial, nasce um aparelho psíquico como "mero princípio organizatório de impulsos somáticos" (ADORNO, 1955/1996, p. 246). Salvo a idade e o linguajar científico do inventor da psicanálise, o que talvez distancie Kafka de Freud seja, nota ainda Adorno, "um ceticismo ainda mais radical em relação ao Ego" reconhecível no escritor tcheco. É a esse esvaziamento da instância egóica "que serve a literalidade de Kafka" (ADORNO, 1955/1996, p. 247). Não é preciso esforço para reconhecer esse viés anti-egóico como mote central da psicanálise de Jacques Lacan, que se voltou à escuta da letra e da incidência dos significantes sobre o sujeito - justamente a literalidade - em oposição a versões hermenêuticas, cujo foco se voltava para o sentido de certos símbolos. Dentre os elementos destacados por Adorno para demonstrar a natureza dos cruzamentos entre Kafka e Freud, talvez não seja demais sublinhar que, em Freud, a literalidade mais radical foi depositada no texto de 1939. Sobre Moisés, Lacan (1959-0/1991) afirma: "[...] se não houve o artigo sobre a Spaltung do ego, poder-se-ia dizer que a pena cai-lhe da mão no final de $O$ homem Moisés e a religião monoteísta. [...] Nada me parece mais firmemente 
articulado, e mais conforme a todo o pensamento anterior de Freud, do que essa obra". (p. 211).

Moisés talvez seja, de fato, o maior testemunho do Freud de Lacan. E isso por conta de questões similares às tocadas por Adorno ao tratar de Kafka. Seguindo ainda na análise do escritor tcheco, feita pelo filósofo frankfurtiano, lê-se que "a força de Kafka é a da demolição" (ADORNO, 1955/1996, p. 247). Depois dela se "alcança a matéria em estado bruto" - algo que "atravessa o homem até chegar ao desumano.". Sem qualquer indício de intencionalidade, "o que antes era metáfora, significado e espírito" reverte-se em "corpo espiritual", reflexo da "postura relaxada [...] tensionada até o dilaceramento" (ADORNO, $1955 / 1996$, p. 247). Veremos cada um desses tópicos, aqui vagamente apresentados, no próximo item, quando será necessário abordar a linguagem do estrangeiro.

Voltemos por enquanto a Who owns Kafka? para desdobrar os argumentos das instituições que disputam o espólio do escritor. Uma delas é a Biblioteca Nacional de Israel. O material de Kafka, alegam seus representantes, não deveria ter sido herdado por Esther Hoffe, namorada de Max Brod, e nem por suas filhas, que querem vender esses "bens" a algum dos vários interessados por um montante significativo, após terem visto o lucro obtido na venda dos manuscritos de $O$ processo. Trata-se, alega David Blumberg, presidente do conselho dos diretores da Biblioteca, de um ativo pertencente ao povo judeu que deveria estar acessível a todos sem custo. O material torna-se a uma só vez, observa Butler, (2011) "ativo" do povo judeu e interesse distante de fins comerciais. "Ativo" não exclusivamente financeiro, Kafka seria escritor judeu que, por isso, deveria estar entre "seu povo". Além de parte dos ativos culturais judaicos, sua escrita seria seu símbolo. Justificativa assaz problemática: era Kafka parte do que se pode chamar povo judeu? Mais: sua escrita representaria realmente esse lugar? Embaraço maior, porém, seria causado se as respostas para estas perguntas fossem afirmativas. Com isso, pondera Butler, também de origem judaica, seria forçoso perguntar: o estado de Israel realmente representa o "povo judeu"? Admitindo como natural o fato de Israel representar o "povo judeu", ignora-se a existência de judeus na diáspora. Nega-se automaticamente também o vasto número de judeus não-sionistas, que não se sentem representados pelo estado de Israel nem legal, nem politicamente. Finalmente não se leva em conta o fato de que palestinos e outros cidadãos não judeus fazem parte do estado. Há estudiosos, como 
Amnon Raz-Krakotzkin, (apud BUTLER, 2011) para quem o exílio e a coexistência são o que define o judaísmo e a judaicidade, o que não condiz com as ideias de povo, sionismo ou Lei do Retorno.

Do outro lado da batalha (BUTLER, 2011) encontra-se o Arquivo Alemão de Literatura em Marbach que, de acordo com acadêmicos alemães, já possui a maior coleção de manuscritos de Kafka no mundo. Entre outras razões, argumentam que a incorporação do espólio ao arquivo impediria a fragmentação da obra. O que é necessário sublinhar, contudo, é a outra razão alegada: Kafka pertenceria à literatura e à língua alemãs. Sob esse argumento, o traço germânico transcende a história da cidadania para exaltar a importância das "competências e realizações linguísticas". Ignora-se, de modo conveniente, o papel do multilinguismo na escrita e na formação de Kafka. É o que expõe Butler:

Focando apenas em como tão perfeitamente alemã é sua língua, $\mathrm{o}$ arquivo se junta a uma longa e curiosa tradição que preza o alemão "puro" de Kafka. George Steiner louvou "a translucidez do alemão de Kafka, sua quietude inoxidável", observando que seu "vocabulário e sintaxe são aquelas da mais extrema abstenção ao desperdício". John Updike referiu-se à "comovente pureza" da prosa de Kafka. Hannah Arendt também escreveu que sua obra "fala a mais pura prosa alemã do século". Então, embora Kafka tenha certamente sido tcheco, parece que este fato é suplantado por sua escrita em alemão, que é aparentemente o mais puro - ou, deveríamos dizer, purificado? Dada a história da valorização da "pureza" no nacionalismo alemão, incluindo o nacionalsocialismo, é curioso que Kafka seja colocado diante desta rigorosa e exclusiva norma. De quais maneiras o multilinguismo de Kafka e suas origens tchecas tem de ser "purificadas" para que ele possa ser colocado como um alemão puro? Será o mais extraordinário ou admirável sobre ele que ele tenha purificado a si mesmo, exemplificando as capacidades de autopurificação do Ausländer? É interessante que estes argumentos sobre o alemão de Kafka estejam re-circulando agora, bem quando Angela Merkel anunciou o fracasso do multiculturalismo na Alemanha e somou, como evidência adicional, a alegação de que os novos imigrantes, inclusive seus "filhos e netos", fracassam em falar alemão corretamente. Ela advertiu publicamente estas comunidades a livrar-se de qualquer sotaque e a "integrar-se" nas normas da comunidade linguística alemã (uma queixa 
rapidamente rebatida por Jürgen Habermas). Com certeza, Kafka poderia ser o modelo do imigrante bem-sucedido, embora ele tenha vivido apenas brevemente em Berlim e, claramente, não tenha se identificado nem mesmo com os judeus alemães. Se os novos trabalhos de Kafka forem recrutados para o arquivo em Marbach, então a Alemanha terá fortificado seu esforço de transferir seu nacionalismo para o nível da língua. A inclusão de Kafka acontece pela mesma razão que as imigrações menos bem faladas são denunciadas e vistas com resistência. É possível que o frágil Kafka possa se tornar norma de integração europeia? (BUTLER, 2011)2.

Nas cartas de Kafka (BUTLER, 2011) para sua amante berlinense Felice Bauer, porém, é possível identificar que "ela corrigia constantemente seu alemão, o que sugere que ele não está completamente em casa nesta segunda língua.". Sua amante tardia, Milena Jesenská, também tradutora de suas obras para o tcheco, ensina a ele frases em tcheco. Ele não sabe como escrevê-las ou pronunciá-las, o que igualmente indica como o tcheco é, para Kafka, uma segunda língua. Em 1911, ele passa a frequentar o teatro iídiche e entende o conteúdo das peças, embora o iídiche não seja uma língua próxima, mas "estranha e constrangedora" (KAFKA apud BUTLER, 2011 citação direta precisa de página). Diante de tudo isso, é natural que Judith Butler levante a seguinte questão: "Então, existe aqui uma primeira língua?" O alemão formal no qual Kafka escreve - que Arendt chamou de o alemão "mais puro" - não traria "sinais de alguém que entra na língua pelo lado de fora?". É esse, aliás, o horizonte de análise de Deleuze e Guatarri (1977/2002) sobre a obra kafkiana:

Kafka diz [...] que uma literatura menor está muito mais apta a trabalhar a matéria. Por quê e o que é esta máquina de expressão? Nós sabemos que ela tem uma relação de desterritorialização com a língua: situação dos judeus que abandonaram o tcheco e simultaneamente o meio rural, mas também situação desta língua alemã como "língua de papel". Pois bem, indo ainda mais longe, procuremos ainda mais além este movimento de desterritorialização da expressão. É que só há duas maneiras

\footnotetext{
${ }^{2}$ Uma versão da tradução da palestra foi feita por Tomaz Amorim Izabel de onde extraí esse trecho. Cf. https://traducaoliteraria.wordpress.com/2014/01/11/a-quem-pertencekafka-de-judith-butler/
} 
possíveis: enriquecer artificialmente esse alemão, ou enchê-lo de todos os recursos de um simbolismo, de um onirismo, de um sentido esotérico, de um significante oculto - é a escola de Praga, Gustav Meyrink e muitos outros como por exemplo, Max Brod. No entanto, esta tentativa implica um esforço desesperado de reterritorialização simbólica baseada em arquétipos, de Cabala e de alquimia, que sublinha o fosso em relação ao povo, encontrando apenas uma saída política no sionismo enquanto "sonho de Sião". Kafka vai muito rapidamente optar pela outra maneira, ou melhor, inventá-la-á. Optar pela língua alemã de Praga, tal como ela é, dentro da sua própria penúria. Ir cada vez mais longe na desterritorialização ... à força de sobriedade. E dado a aridez do léxico, fazê-lo vibrar em intensidade. Opor um uso puramente intensivo da língua a qualquer utilização simbólica ou mesmo significativa, ou simplesmente significante. Chegar a uma expressão perfeita e não formada, uma expressão material intensa. (p. 42-43).

Essa breve apresentação sobre os impasses em torno do espólio de Kafka e sobre a língua na sua escrita permite finalmente introduzir um dos problemas concernentes a este estudo: qual seria a linguagem própria ao estrangeiro? Kafka não está em casa quando habita Praga, nem se sente um alemão. Tampouco está inteiramente convencido de sua identidade judaica. Esse constante oscilar desgarrado emerge na forma literária de seus escritos. Dessa dessubjetivação Kafka extrai o rumor das coisas, sempre estranhas em sua língua. Sua pura língua está, assim, longe de ser uma via de mão única. Ela certamente não é expressão de alguma identidade nacional ou de sangue do escritor. Há nela, porém, uma pureza. Como se os murmúrios das máquinas e de suas engrenagens ganhassem um tradutor fino - a linguagem pura é a linguagem rente às próprias coisas. A interpretação que Judith Butler faz de Hannah Arendt é, nesse sentido, imprecisa. Vejamos o que a filósofa judia-alemã diz em "Franz Kafka: a revaluation":

Kafka - em contraste marcante com outros autores favoritos da intelligentsia - sem estar engajado a experimentos técnicos de espécie alguma, sem mudar de nenhum modo a língua alemã, despojou-a de seus invólucros construtivos até que ela se tornasse clara e simples, como o discurso diário purificado de jargões e negligência. A simplicidade, a naturalidade fácil de seu idioma, talvez indique que a modernidade de Kafka e a dificuldade de seu 
trabalho têm muito pouco a ver com essa complicação moderna da vida interior [...]. (ARENDT, 1944/1994, p. 69-70).

Pureza diz respeito aqui a certa limpidez. Uma linguagem que, sendo estrangeira, está liberta do Geist germânico. Geist entranhado de certas convenções, etiquetas, limites morais ou cacoetes acadêmicos compartilhados. Sem compromisso com essas regras de salão - que imperceptivelmente moldam também a literatura -, o estrangeiro Kafka faz caminhos surpreendentes pela língua. Como qualquer desbravador, capaz de notar de maneira fina a estranheza de uma cultura que não é a sua, a condição de estrangeiro faz de Kafka uma espécie de Debret ou Saint-Hilaire da modernidade. O olhar estrangeiro que depõe sobre as coisas o frescor do impacto parece semelhante entre esses homens e Kafka, mas o paralelo não é inteiramente preciso por um único motivo: esses exploradores importavam a episteme de seus países para o registro daquilo que descobriam. Estavam apegados, é evidente, à velha racionalidade colonizadora. Kafka, bem ao contrário, não tem como importar nada. Sua origem é um não-lugar. Daí que sua forma literária seja extraída também da estranheza das coisas - trata-se de uma episteme literária sem herança, voltada à consistência inquietante de aspectos naturalizados pelos olhos humanos.

Embora Kafka dominasse o idioma alemão, há um descolamento entre seu espírito e essa língua. Cenas labirínticas, constantes em sua obra, talvez sejam o melhor retrato do modo como ele tateia as bordas da língua: gira em círculos, perde-se, vaga no escuro, topa com objetos ou pessoas inesperadas. Quase sucumbe ante o desconhecido. Quando se defronta com algo surpreendente, a trama se rearticula. O estrangeiro é determinado por essa lacuna ou falta de aderência natural entre Kafka e a língua na qual escreve.

É possível que esses aspectos façam do alemão kafkiano uma língua mais pura, atributo com o qual até mesmo Benjamin talvez não discordasse. Sobre o pequeno conto Diante da lei, o filósofo declara em uma carta de 21/07/1925 a Gerhard Scholem: "Diante da lei é considerado por mim hoje, como há dez anos, um dos melhores em alemão" (BENJAMIN, 1925/1978, p. 397). Como o personagem do próprio conto Diante da lei, acima mencionado, a língua não é o território ao qual Kafka tem livre passagem - alocada em um limiar, a linguagem só existe como uma conquista insólita.

Encarnar essa condição de estrangereidade à linguagem kafkiana foi o que lhe concedeu um lugar incomum. Günther Anders (1946/2007), 
aliás, fala de Kafka como alguém que rebatiza. Não se trata, para Anders, de um ato consciente de tradução em Kafka, mas de promover um persistente embaralhamento de etiquetas, descolando aquelas que parecem naturalmente aderidas aos objetos e depositando-as sobre outros nomes. A definição que Kafka (1966/2008) dá à figura de Odradek talvez indique com maior precisão a forma da linguagem do escritor:

Dizem alguns que a palavra Odradek provém do eslavo, e procuram determinar a formação da palavra com base nesta afirmação. Já outros acreditam que ela provenha do alemão, do eslavo teria apenas a influência. A incerteza das duas interpretações autoriza entre- tanto a supor que nenhuma delas acerta, mormente porque nenhuma nos leva a encontrar um sentido para a palavra. (p. 22).

Nem tcheco - eslavo - nem alemão, a palavra Odradek colocase no vazio para adquirir sua consistência própria. Uma das etimologias de "eslavo", explicam Pucheu e Trocoli (2014), remete aos termos "palavra", "conversa", "fala", "língua", indicando o idioma desse povo. Tcheco deriva, por sua vez, do nome do líder - Cech - de uma tribo eslávica que se autodenominava Cechové. O líder conduziu seu povo a um assentamento em determinado lugar. Em sua origem, tcheco quer dizer "membro do povo, gente aparentada". Não sendo eslavo ou especificamente tcheco, nem alemão Kafka está desterritorializado e sem língua comum. Murmurando sons distantes da língua articulada, há apenas terreno para o que está destituído de sentido. Odradek é a forma do sem sentido, ou melhor, daquilo que adquire algum contorno fora de qualquer lugar previamente determinado.

Sem verter a língua própria para a estrangeira ou vice-versa, a língua de Kafka é, em qualquer parte, sempre estrangeira. Ainda assim, refletir sobre a forma da tradução é a melhor maneira de tratar o estilo literário de Kafka. Walter Benjamin (SELIGMANN-SILVA, 2007) foi o filósofo que fundou uma "ciência da tradução" que não se ocupa apenas do ofício de verter textos de um idioma para outro, abrindo campos epistemológicos e estéticos inéditos. 


\section{Traduzir: gesto do estrangeiro}

Em A tarefa do tradutor, Walter Benjamin (1921/2011) ainda está às voltas com sua enigmática teoria da linguagem, apresentada em Sobre a linguagem em geral e sobre a linguagem do homem de 1916. Linguagem que está em tudo que existe e na qual se manifesta também a vida espiritual humana. Aliás, "é essencial a tudo" - e não apenas aos homens -, diz Benjamin, "comunicar seu conteúdo espiritual" (BENJAMIN, 1916/2011, p. 51) pela expressão. O homem comunica sua própria essência espiritual ao nomear todas as outras coisas na língua, feita de palavras. Embora seja evidente que existam outras linguagens, somente a essência linguística do homem nomeia as coisas. Em outras palavras: o comunicável em uma essência espiritual é justamente sua essência linguística, sendo a do homem composta de nomes. Compreender a essência linguística, por sua vez, implica voltar-se para a essência espiritual de que é a manifestação imediata. Mas ambas - essência espiritual e essência linguística - não coincidem; embora se comunique na língua, a essência espiritual não é a própria língua e nem se comunica através da língua.

Vale a pena reivindicar uma pausa. Cada frase de Sobre a linguagem em geral e sobre a linguagem do homem coloca o leitor num torvelinho. $\mathrm{O}$ apelo que elas fazem à nossa compreensão fica claro pelo número de vezes que somos obrigados a voltar ao texto. Não raro, comentadores renunciam à tarefa de as compreender de modo fino, subentendendo que há mistérios indecifráveis inerentes à escrita benjaminiana, dignos, talvez, de sua herança mística judaica. Não é o que entendemos aqui. Walter Benjamin, aliás, é categórico ao dizer, ali mesmo, que "quanto mais profundo, isto é, quanto mais existente e real for o espírito, tanto mais exprimível e expresso" (BENJAMIN, 1916/2011, p. 59). Em geral, diz ele ainda, o inexprimível é tido como a última essência espiritual. Mas, ao equiparar a essência espiritual à essência linguística, Benjamin contesta a relação de proporcionalidade inversa entre ambas. Como ele diz: "aquilo que existe com mais força na linguagem, aquilo que está melhor estabelecido, aquilo que é, em termos de linguagem, mais pregnante e inarredável, em suma, o que mais se exprime, é ao mesmo tempo espiritual em sua forma pura" (BENJAMIN, 1916/2011, p. 59).

Há, porém, algo que resiste à linguagem. Isso que resiste não é a essência espiritual. Se a linguagem humana é feita de palavras e sua essência espiritual só pode ser expressa pela essência linguística, não 
se pode dizer que tudo no homem se reduz às palavras - sangue, pele, pêlos, poros, rugas, unhas. Calafrios, arrepios, dores, ardência, tremor, palpitação. Sono, vigor, indolência, ânimo. São palavras. Mas são palavras que expressam toda a essência linguística desses aspectos e estados, sem, porém, dar conta de abarcar tudo o que eles efetivamente são. Benjamin não se rendeu aos exemplos, pois fazê-lo - como o fiz aqui - significa já falar na linguagem e não de outra coisa. Mais claramente: ao dizer sono já estou situada em uma espécie de linguagem que não diz a própria coisa. O bocejo espontâneo, no momento exato em que se manifesta, talvez seja a linguagem mesma do sono. E o sono não é o homem. O sono é a coisa em si que pode estar igualmente presente em animais. Daí ser a língua o que expressa a essência espiritual do homem - e não do sono ou do ânimo que ele sente. O ânimo e o sono têm, como os animais, essências linguísticas próprias.

Longe de apelar para o inefável ou para um além indecifrável pela sua superioridade intangível e transcendental, Benjamin volta às próprias coisas. E nem tudo se expressa pelas palavras. Numa espécie de looping em torno da linguagem, Benjamin afirma que esta comunica a essência espiritual das coisas, e, ao mesmo tempo, diz que a manifestação mais clara dessa essência é a própria linguagem. No verbo "é", diz ele, concentra-se a chave: o elemento comunicável é a linguagem mesma sem mediações. Ou seja, não faz sentido dizer que aquilo que em uma essência espiritual é comunicável se manifesta mais claramente na sua língua, pois a língua de uma essência espiritual é imediatamente aquilo que nela é comunicável. Sem língua, a essência espiritual apaga-se e passa a não existir.

Essa espécie de imediatez, contudo, reflete a língua paradisíaca, cujo conhecimento era perfeito. Após a queda, o conhecimento fica condenado à multiplicidade infinita da linguagem. Do alto da árvore, a serpente seduz para o conhecimento sobre o bem e o mau. Saber destituído de nome. Esse conhecimento nulo era o único mal existente no estado paradisíaco. Longe de ser imanente como o nome, conhecer o que é bom e o que é mau é artifício que advém de fora e simplesmente mimetiza a palavra criadora.

Nesse conhecimento, o nome sai de si mesmo: o pecado original é a hora de nascimento da palavra humana, aquela em que o nome não vivia mais intacto, aquela palavra que abandonou a língua que nomeia, a língua que conhece, pode-se dizer: abandonou a sua própria magia imanente para reivindicar expressamente seu 
caráter mágico, de certo modo, a partir do exterior. A palavra deve comunicar alguma coisa (afora si mesma). Esse é realmente o pecado original do espírito linguístico. A palavra que comunica do exterior, expressamente mediada, é de certa forma uma paródia da palavra imediata, da palavra criadora de Deus; é também a queda do espírito adâmico, do espírito linguístico bem-aventurado, que se encontra entre ambos. (BENJAMIN, 1916/ 2011, p. 67).

Enquanto do nome emana o conhecimento das coisas, o saber sobre o bem e o mal é prolixo, sem nunca se deter a elas. Essa palavra que julga concentra sua magia no fato de ser meio. Esquiva e sem a aderência perfeita à coisa, essa linguagem é mero signo que instaura uma proliferação de línguas. Na infeliz magia do julgamento, localiza-se "a origem da abstração”. Para Benjamin (1916/2011):

A imediatidade [...] da comunicabilidade própria à abstração reside no veredicto judicial. Essa imediatidade na comunicação do abstrato instalou-se como judicante quando o homem, pela queda, abandonou a imediatidade na comunicação do concreto, isto é, o nome, e caiu no abismo do caráter mediado de toda comunicação, da palavra como meio, da palavra vã, no abismo da tagarelice. Pois - é preciso repetir ainda uma vez - a pergunta sobre o bem e o mal no mundo depois da Criação foi tagarelice. A árvore do conhecimento não estava no jardim de Deus pelas informações que eventualmente pudesse fornecer sobre o bem e o mal, mas sim como insígnia do julgamento sobre aquele que pergunta. Essa monstruosa ironia é o sinal distintivo da origem mítica do Direito. (p. 68-9).

Nessa língua, "os signos se confundem" e "as coisas se complicam". O descolamento entre coisas e nomes é o que dá margem à servidão. Pelo julgamento houve desentendimentos insuperáveis, cuja representação é a confusão das línguas e a construção da torre de Babel.

Há, porém, na teoria benjaminiana da tradução uma forma de linguagem que se mantém entre a linguagem que nomeia e aquela que julga, descolada da coisa. Palavras sempre expressam o esforço de traduzir manifestações espirituais em linguagem - o espírito é, aliás, o próprio processo dessa tradução. Dito de outro modo: se a essência espiritual do homem se expressa na língua, ele, que fala de todas as coisas, vive um incontornável descompasso entre o que profere e o que quer designar. A lacuna entre ele e todas as coisas impõe esse continuo processo de 
tradução. Com efeito, linguagem humana é também tradução - somente na medida em que é tradutor, o homem expressa sua essência espiritual. Já estamos em áreas próximas às que foram examinadas sobre Kafka, mas também não estamos muito distantes de Freud. Numa carta a Fliess, escrita em 06/12/1896, Freud (1896/1986) descreve como as excitações psíquicas exigem processos constantes de tradução até alcançar a palavra.

Mencionamos anteriormente como Adorno, ao traçar analogias entre Freud e Kafka, percebe bem essa característica ao dizer que o aparelho psíquico nasce como "mero princípio organizatório de impulsos somáticos". Talvez a expressão "corpo espiritual", empregada por Adorno naquele contexto, tenha sido melhor sucedida do que a "essência espiritual" adotada por Benjamin. Também vimos como, para o filósofo frankfurtiano, "o que antes era metáfora, significado e espírito" reverte-se, tanto na obra de Kafka, como na de Freud, em "corpo espiritual". Condensar corpo e espírito numa única expressão, como faz Adorno, permite que se perceba como a linguagem é desdobrar da materialidade corpórea em nomes.

Como na tradução nada se comunica através da língua, aquilo que se comunica $n a$ língua não pode ter uma régua que a delimite do exterior; essa comunicação na língua, e não pela língua, é o que faz dela infinita em seu gênero - cada essência espiritual apela por sua própria expressão em uma essência linguística. Logo, não há designação externa à própria essência espiritual e esgarçar as fronteiras linguísticas pelo gesto de tradução significa ampliar a própria essência espiritual. Benjamin extrai um trecho de Crise da Cultural Europeia de Pannwitz capaz de explicitar suas ideias:

Nossas traduções (mesmo as melhores) partem de um falso princípio, elas querem germanizar o sânscrito, o grego, o inglês, ao invés de sanscritizar, grecizar, anglicizar o alemão. Elas possuem um respeito muito maior diante dos próprios usos linguísticos do que diante do espírito da obra estrangeira... O erro fundamental de quem traduz é apegar-se ao estado fortuito da própria língua, ao invés de deixar-se abalar violentamente pela língua estrangeira. Sobretudo quando traduz de uma língua muito distante, ele deve remontar aos elementos últimos da própria língua, onde palavra, imagem e som se tornam um só; ele tem de ampliar e aprofundar sua língua por meio do elemento estrangeiro; não se tem ideia em que medida isso é possível, até que ponto cada língua pode se transformar [...]. (apud BENJAMIN, 1926/2011, p. 117-8). 
O abalo violento sofrido pela língua, quando exposta ao idioma estrangeiro, pode ser justamente o que Adorno reconheceu em Kafka ao falar sobre sua "força de [...] demolição"(ADORNO, 1955/1996, p. 247). Somente no processo de traduzir se "alcança a matéria em estado bruto" (ADORNO, 1955/1996, p. 247). Pois traduzir é sempre debater-se com aquilo que se expressa linguisticamente do corpo espiritual. Esse modo de pensar a linguagem que "atravessa o homem até chegar ao desumano" (ADORNO, 1955/1996, p. 247) está de fato muito distante do modo como os críticos dos anos 20 leram Kafka. Hannah Arendt acerta ao perceber que tais leitores "procuraram [...] interpretações, aparentemente mais profundas, e as encontraram, seguindo a moda do dia, em uma descrição misteriosa da realidade religiosa, expressão de uma terrível teologia.”. (ARENDT, 1944/1994, p. pp. 71-2). Cerce ao desumano, Kafka se despe das coberturas do espírito. Adorno, vimos, enxerga o esvaziamento de qualquer indício de intencionalidade na linguagem de Kafka. Como tradução, sua linguagem faz trepidar as próprias coisas até seu dilaceramento no nome.

\section{Moisés como tradutor}

Moisés talvez seja aquele que transmitiu aos outros homens o dom da tradução pelo nomos - as leis divinas convertidas em texto sagrado. No nomos concentra-se a vontade divina capaz de criar os contornos de um novo idioma - o do judaísmo. Distante da ideia de similitude, na qual impera a tentativa inglória de traduzir núcleos abstratos de uma língua para outra, traduzir a linguagem das coisas para a linguagem do homem implica engendrar nome ao que está destituído dele. Tarefa cuja imagem é a escrita do Pentateuco, livro de Moisés, mas também o texto freudiano, dedicado ao profeta.

Freud exerceu o ofício de traduzir sombras. Entretanto, o fazia apoiando-se em nomes já aceitos por certas convenções científicas ou culturais. Com seu Moisés, Freud dá um salto para outras margens nas quais reverberam sublevações políticas e a institucionalização de novas leis nas quais o que prevalece é tradução de uma mestiçagem indefinida de etnias e culturas que cultuam o indeterminado e redigem nachträglich aquilo que se sucedeu após os riscos assumidos no sonho de libertação. Embora Freud diga ser Moisés uma espécie de continuação de Totem e tabu, essas raízes, no texto freudiano dedicado à história mosaica, 
emergem como expectativa de fundar leis cujo princípio é o de expressar e habitar aquilo que é estrangeiro no homem.

As palavras proferidas pelo povo no Exxodo não são menos importantes do que aquelas proferidas por Moisés. O povo murmura sons de forme e de sede. O murmúrio é a expressão mais indiferenciada e impotente da linguagem; lamentar é quase um suspiro sensível que se reúne ao rumor do vento na folhagem. Lamenta-se quando a palavra esgota sua capacidade de expressar a miséria e a precariedade. Moisés escuta seu povo e interpela Deus, que responde concedendo as dádivas reclamadas. Essas línguas todas traduzidas institui uma organização social na qual não prevalece uma única voz - a do pai primevo arbitrário e feroz. Reconhecer o fundamento da pluralidade das línguas implica adotar o princípio da tradução como único capaz de instituir a igualdade entre as diferenças. Não por um movimento de encontrar equivalências, mas sim por um exercício continuo de engendrar existências e experiências comuns.

Definindo-se ante seu povo, com quem não tem nenhum traço familiar comum, como "Eu sou o que sou”, Moisés não encontra apoio em definições sobre sua identidade. A própria caracterização de seu nome por Freud é curiosa. Escavando as raízes etimológicas, claramente distantes das versões talmúdicas - "porque das águas o tirei” -, o nome Moisés viria de 'mose' que quer dizer filho em egípcio e é abreviatura de formas mais completas, como Amen-mose (filho de Amon), Ptah-mose (filho de Ptah) e assim sucessivamente. Ora, de onde vem exatamente Moisés? Qual sua origem? É filho de quem? Simplesmente filho - de ninguém? Sem origem, que língua exatamente ele fala? Ele fala bem alguma língua? A religião mosaica é epígono da religião de Aton, caracterizada negativamente por Freud por excluir tudo que é místico, mágico, encantatório. Como diz Weigall (apud FREUD, 1939/2014): Akhnaton não permitiu que se fizesse qualquer imagem gravada de Aton. O verdadeiro Deus, dizia o rei, não tem forma. Qualquer existência evidentemente assume uma forma. Entretanto, a forma de Aton não pode ser simbolizada ou representada por outra figura. Sob o legado de Aton, Moisés é o que é, ou melhor, só pode ser sendo no exato momento em que as formas de suas manifestações irradiam de seu corpo no espaço e no tempo.

$\mathrm{Na}$ comparação feita por Freud entre a religião mosaica e a religião de Aton, a fronteira tão fortemente estabelecida entre Oriente e Ocidente passa a derreter e um jogo de sobreposições se desenha, sem que os contornos precisos de cada um possam ser reconhecidos. O que 
é propriamente egípcio e o que é propriamente judaico aparece em um horizonte nebuloso, cujas linhas não se distinguem. Como Kafka que não era alemão, tcheco ou judeu, a figura de Moisés não é judaica, egípcia ou midianita. Seu judaísmo é a invenção de uma outra linguagem que, embora tenha sua raiz em Aton, já não é mais aquela religião. Distante da imagem do sol, o Deus da religião judaica é ora universal e destituído de forma, ora "demônio sinistro, sedento de sangue, que vaga pela noite e teme a luz do dia". O "povo judeu”, por sua vez, é uma composição dos escravos que saíram do Egito e outras tribos aparentadas que permaneciam entre Egito e Canaã - sabe-se lá que língua transcorria entre essa mescla de pessoas. (MEYER apud FREUD, 1939/2014, p. 65). Nos comentários sobre o Exodo, escritos por Grenzer e Fernandes (2011), lê-se "o êxodo não pode ser avaliado como projeto nacional unicamente israelita. Pelo contrário, prevê-se a libertação do povo inteiro dos oprimidos". (p. 12) O plano de saída da sociedade opressora, explicam, significa sair rumo ao deserto [grifo dos autores]. Etimologicamente deserto quer dizer em hebraico "sem palavra" (...). Quando estão no deserto, os sujeitos não articulam bem as palavras, mas murmuram continuamente para Deus como tentativa de nomear certa precariedade material.

Nessas diversas passagens do Êxodo em que o povo de Israel murmura contra Moisés em momentos de fome e sede, a resposta que escutam do líder é sempre a mesma: "Quem sou eu, para que murmureis contra mim”. Moisés não é ninguém. Ele manifesta e traduz os desejos de Deus, mas Deus também se molda pelos murmúrios do povo. Estes nascem de exigências somáticas - de um lado, Moisés busca traduzir a voz oscilante do corpo, de outro a voz do indeterminado.

\section{Os nós de Freud - entre Kafka e Moisés}

Chegamos a alguns impasses. O paralelo entre Kafka e Moisés, estabelecido pelo caráter estrangeiro de suas linguagens e pela forma linguística da tradução, encontra obstáculos na própria obra freudiana dedicada ao exame das origens do profeta. Como Kafka, Moisés tateia e profere nomes. Contudo, ainda que interpele Deus ao escutar os murmúrios de seu povo, Moisés registra, nas escrituras, a língua que reverbera de Deus. Como vimos, não é incomum que a escrita kafkiana seja vista como despida de atributos do espírito [Geist], ficando rente à materialidade e às manifestações que tocam o desumano nos homens. Se 
por um lado o texto freudiano é formalmente revolucionário, trazendo conteúdos condizentes com essa forma, por outro Freud ainda faz questão de frisar expressamente ali a superioridade do pensamento abstrato sobre o sensível. A religião de Moisés, lembra Freud, que proíbe fabricar a imagem de Deus e determina a adorá-lo sem nenhuma forma visível, gera mudanças psíquicas e culturais profundas, ligadas à substituição da percepção sensorial pela faculdade de abstração. O "triunfo da intelectualidade sobre a sensualidade" (FREUD, 1939/2011, p. 157), observado por Freud, implicaria ainda na renúncia instintual. O abandono do matriarcado pelo nome que se herda do pai também representaria essa substituição. Pontos que são considerados, pelo pai da psicanálise, como avanços de grande magnitude para as civilizações.

Não é necessário muito esforço para relembrar análises frankfurtianas e de outros filósofos contemporâneos, ou a própria obra de Kafka e de Freud, para levantar a pergunta: o que leva Freud a insistir nessa trilha? A falência do pensamento abstrato, aliás, ficou mais patente do que nunca nos modelos de racionalidade que levaram aos campos de concentração nazista, contemporâneos ao próprio texto. Diante disso, como é possível que Freud considere, sem qualquer receio, a superioridade da abstração sobre a sensorialidade e do patriarcado - abstraído na modernidade pelos órgãos institucionais - sobre o matriarcado? Não se trata de simplesmente inverter os sinais em uma solução automática e afirmar agora a superioridade do matriarcado sobre o patriarcado ou da sensorialidade sobre o pensamento abstrato, mas é o caso de refletir sobre os limites e possibilidades dessas formas de racionalidade e observar que o caminho da mestiçagem - ou a categoria de estrangeiro - talvez seja uma alternativa interessante para alguns de nossos modelos civilizatórios. Nesse modelo, a tarefa contínua de tradução é o que perfaz a linguagem, sem recair na abstração vã do julgamento e sem a ilusão de imediatidade própria à linguagem divina.

\section{Agradecimentos}

Agradeço à FAPESP por financiar minha pesquisa. 


\section{Referências}

ADORNO, T. Anotações sobre Kafka. In: Prismas. São Paulo: Ática, 1996.

ANDERS, G. Kafka: pró e contra. São Paulo: Cosacnaify, 2007.

ARENDT, H. Kafka: a revaluation. In: Essays in Understanding 19301954. New York, San Diego, London: Harcourt Brace \& Company, 1994.

BENJAMIN, W. Sobre a linguagem em geral e sobre a linguagem do homem. In: Escritos sobre mito e linguagem. São Paulo: Editora 34, 2011.

BENJAMIN, W. A tarefa do tradutor. In: Escritos sobre mito e linguagem. São Paulo: Editora 34, 2011.

BENJAMIN, W. Brief an Gerhard Scholem 21/07/1925. In: Briefe I. Frankfurt am Main: Suhrkamp Verlag, 1978.

BUTLER, J. Who owns Kafka? London review of books, Winter Lectures, 2011. In: https://www.youtube.com/watch?v=234npiDz-SE. Acesso: 10 set. 2017.

DELEUZE, G; GUATARRI, F. Kafka para uma literatura menor. Lisboa: Assírio e Alvim, 2002.

FREUD, S. O homem Moisés e a religião monoteísta. Porto Alegre: L\&PM, 2014.

FREUD, S. O Moisés de Michelangelo. In: Obras Psicológicas Completas de Sigmund Freud. Rio de Janeiro: Imago, 1996.

FREUD, S. A correspondência completa de Sigmund Freud para Wilheim Fliess. Rio de Janeiro: Imago, 1986.

GRENZER, M.; FERNANDES, L. A. Êxodo. São Paulo: Paulinas, 2011. KAFKA, F. A tribulação de um pai de família. In: Schwartz, R. O pai de família. São Paulo: Companhia das Letras, 2008.

LACAN, J. O Seminário, livro 7. A ética da psicanálise. Rio de Janeiro: Jorge Zahar, 1991.

PUCHEU, A.; TROCOLI, F. Passagens de Franz Kafka. In: Revista Cult, 194, setembro de 2014. 
STRACHEY, J.) Nota do editor inglês ao Moisés e o monoteísmo. In: Freud, S. Obras Psicológicas Completas de Sigmund Freud. Rio de Janeiro: Imago, 1996.

Recebido em: 20 de outubro de 2017. Aprovado em: 06 de fevereiro de 2018. 